\title{
A SURVEY OF MOTIVATION IN EFL CLASSES FROM THE PERSPECTIVE OF LEARNERS AND TEACHERS
}

\author{
Ahmed Mohammed ALQUYADI ${ }^{1}$ \\ Bakil Ali ALWALSS*2 \\ English Language Institute, Jazan University, Saudi Arabia \\ 1aquyadi@jazanu.edu.sa \\ ²balwalss@jazanu.edu.sa *
}

Manuscript received 18 July 2020

Manuscript accepted 24 August 2020

${ }^{*}$ Corresponding author

https://doi.org/10.33736/ils.2434.2020

\begin{abstract}
Incentives, drives and motivation are the main terms in psychology that strengthen the persistence towards the desired achievement. This paper investigates teachers and students' perception of how motivation can be promoted and consolidated in the EFL classroom. More precisely, how teachers can raise the level of motivation inside and outside the language classroom. The significance of this study lies in the fact that once learners are motivated, they can easily realise that they are achieving a purpose of their language learning and that they are more willing to accept the challenge of some demanding tasks. In this study two questionnaires were used: one for 46 teachers (in English) and one for 75 students (in Arabic). Teachers were in favour of almost every item related to motivation, and their average scores were higher of than that of the students. Probably experience and knowledge of the issue played a major factor. In general, the questionnaires for both groups yielded higher results than the calculated average for every group; for teachers, it was $72 \%$, and it was $60 \%$ for the students. In conclusion, encouragement, appraisal, and motivation are important in classroom activities to raise language learning awareness and learning persistence.
\end{abstract}

Key words: motivation; classroom learning awareness; EFL; EFL learners

\section{Introduction}

Globalisation has resulted in the need for a common language in the world in order for people to communicate effectively with each. Thus, English has become a global medium of communication as it is used worldwide as a lingua franca. Arabic learners who speak English as a foreign language (EFL) usually face a number of difficulties when they get to university learning level since English is the medium of instruction for the majority of the courses taught. Motivating these learners is largely 
dependent on the teachers and others concerned with the learning process. One of the influential determinants of EFL learning is motivation, and this has long been identified as of great influences (Dörnyei \& Ryan, 2015; Moskovsky, Alrabai, Paolini, \& Ratcheva, 2013; Spolsky, 1990).

Al-Rabai $(2014$, p. 225$)$ has the view that although "[m]otivation is a key factor in the acquisition of second and foreign languages, it is widely acknowledged that Saudi EFL learners generally do not possess very high levels of second language (L2) motivation". Ekiz and Kulemtov (2016) remind us that teachers and researchers have acknowledged that motivation or demotivation plays a role in the progress and success of foreign language (FL) learning. In a recent study, Ho (2016, p. 68) shows that patience and motivation, along with others, scored higher than other factors in bringing about better vocabulary learning. Other beliefs included factors related to teachers' positive feelings, learners' styles, and positive backwash effect of testing. What is of immediate interest to this research is how EFL learners can increase their motivation to learn the language.

\section{Research questions}

The aim of this research is to investigate how teachers of English can increase the motivation level of their students. Specifically, the objectives are as follows:

- From the point of view of students, what are the most common techniques that teachers should use to motivate students to learn English?

- From the point of view of teachers, what are the most common techniques that teachers should use to motivate their students to learn English?

- Are teachers and students aware of the importance of motivation in learning English?

\section{Significance of the research}

Motivation is among the most significant factors that can enhance learning of a language. Thus, the success of language learning depends, to a large extent, on how motivated they are (Brown, 1994; Cheng \& Dörnyei, 2007). It is worth highlighting here that with the rise of learner-centeredness, teachers have to look into elements that help develop this learner-centeredness, which can be motivation. When learners are highly motivated, they are able to realise that they are achieving a purpose of their language learning, accept some demanding tasks and understand that they are gaining success as they progress in their FL learning (Al-Kaboody, 2013; Bahous, Bacha \& Nabhani, 2011; Ramage 1992).

\section{Literature Review}

Motivation is described a drive that pushes or incites people to take actions, or do tasks or activities (Clément, Dörnyei, \& Noels, 1994; Dörnyei, 2005; Dörnyei, 2011). Dörnyei $(1998$, p. 117) maintains that "although motivation is a term frequently used in both educational and research contexts, it is rather surprising how little 
agreement there is in the literature with regard to the exact definition of the concept".

It is important to shed some light on the two types of motivation: the instrumental or extrinsic versus the integrative or intrinsic. In the instrumental type, learners are interested in learning a language for practical purposes, for example getting a degree, or getting a job. In this type of motivation, usually there can be an immediate benefit for the person. On the other hand, learners who are integratively motivated are interested in getting integrated with the speakers of the target language, its society and culture (Brown, 1994).

Dörnyei $(1998$, p. 118) believes that "motivation has been widely accepted by both teachers and researchers as one of the key factors that influence the rate and success of second or foreign language learning." In a similar manner, Tuan (2012) confirms the role of motivation in language learning, and others (such as Rehman et al., 2014) reiterate that motivation is of immense importance in achieving the desired goals of language learning.

As far as the debate regarding whether the instrumental or integrative type matters most, Dörnyei and a number of his contemporaries agree that in an EFL context, instrumental motivation plays a greater role in language learning (Dörnyei, 1994, 2001, 2003). Some studies, for example, (Al-Kaboody, 2013) revealed a need for a more pragmatic education centred approach. This indicates that EFL teaching/learning settings should be largely instrumentally oriented.

\section{Why motivation?}

Lamb (2016) stated that one cannot imagine a group of learners learning a second or a foreign language without a certain level of motivation. Thus, the influence or rather the relationship between motivation and language learning has been wellestablished among those concerned, to name a few, (Spolsky, 1990; Cranmer, 1996). Motivation must be there because from a psychological point of view, human beings are complex creatures so they have complex desires, complex needs, complex moods and different feelings and reactions towards certain stimuli, which all have their influences on learning. In sum, it is natural that they are different. This is why we say that for learning to happen, the required degree of motivation should exist in the classroom, which will enable teachers to teach effectively (Ramage, 1990; Dörnyei, 1998; Chambers, 1999; Dörnyei, 2005). Dörnyei (1994, p. 273) reiterates that there has been a great deal of investigation into "the nature and role of motivation in the L2 learning process". Again, Dörnyei (1998, p. 117) adds that "motivation energises human behaviour and gives it direction". Therefore, it is widely believed that students start to see learning as rewarding particularly when they are highly motivated.

\section{The role of the teacher}

It goes without saying that the teacher is the cornerstone of any teaching-learning situation and its process. This the view held by so many researchers and educators (Al-Kaboody, 2013; Assalahi, 2013; Bahous, Bacha, \& Nabhani, 2011; Brown, 1994; 
Cook, 2013; Davis, 2003; Dörnyei, 2001, 2003; Lightbown \& Spada, 2006; Reeve \& Jang, 2006; Spolsky, 1990; Williams \& Burden, 2002).

And in order to make such a process a success, the teacher is to create the required amount of motivation that can make the teaching-learning process continue as much as possible. Nadeem (2013, p. 209) confirms that the teacher is supposed to "play a highly significant role in creating motivation strategies" that can make the teaching practice motivational. The teacher has to be motivated to be able to create that required level of motivation. Gonzales (2010) explains that the idea of teacher as a friend, a guide, an inspiration provider, a source of knowledge and a role model is not new as it has been there for centuries. Koran $(2015$, p. 38$)$ adds that "[t]eachers are seen as the major determinant sources of motivation for language learners ... and are, further, expected to enhance learners' motivation for better language learning." Al-Kaboody (2013, p. 45) goes further to say that "teachers have a huge responsibility to initiate learners' motivation and keep it alive throughout the learning process". Teachers play a central role in motivating learners; therefore, we can conclude by saying that creating and consolidating motivation in class depends highly on the teacher.

Teachers are, with no doubt, the providers of motivation. This is because they are the people who feed the learners' minds with knowledge, skills and information. While parents raise their children biologically, teachers raise them mentally to become successful learners. It is stressed by Assalahi $(2013$, p. 1) that teachers have gained this high position "through in-service teacher education, college preparation" and the experiences gained from their field. This means teachers should be aware of observing motivation while teaching and subsequently to create awareness of learning and motivation for their learners.

\section{Methodology}

The participants in the study were 75 students and 46 teachers. The students were in their first and second year of their degree programme in sciences, medicine, and engineering from three colleges at Jazan University. The teachers had received inservice training through seminars and short sporadic training sessions. Therefore, it is important to investigate their opinions on the importance of motivation in the language classroom. A number of researchers advocated teachers' views on the development and students' involvement in the learning process as crucial (Borg, 1998; Dörnyei, 2008; Dörnyei \& Ushioda, 2011Moskovsky, Alrabai, Paolini, \& Ratcheva, 2013; Ruesch, Bown, \& Dewey, 2012; Tuan, 2012;).

Two questionnaires were designed and developed based on Cohen, Manion, and Morrison (2007, pp. 317-348). The questionnaire for students was originally in Arabic to make sure that the students fully understood the items. It was later translated to English (Appendices A \& B). To construct the questionnaires, the researchers held informal discussions with colleagues from the English Language Institute of Jazan University regarding item coverage and topics as well as wording and sequencing. Selection of these statements was done through combining and paraphrasing many statements related to the topic in question. Later on, similar discussions were held with other colleagues for further checking and a small-scale 
piloting. A five point-Likert scale was chosen to measure the teachers' and students' attitude towards motivation during the English lesson in the classroom.

Both questionnaires were provided to the judges in English. The judges were two PhD holders in applied linguistics at the English Language Institute of Jazan University. The questionnaire for the teachers included 24 statements (Appendix A), and the questionnaire for the students contained 20 statements (Appendix B). The printed questionnaires were distributed during classes in the first semester 2020. To observe privacy and level of freedom for doing the research, names were not required, and completion of the questionnaire was optional. This measure may have slightly affected the turn-out of the questionnaires.

The statistical analysis focused on calculating percentages and values for each item. Brace (2004, p. 86) states that "[r]esponses using the Likert scale can be given scores for each statement, usually from 1 to 5 , negative to positive". Since our questionnaires were based on similar responses' scale, we adopted a simple tallying analysis. The procedure we used to analyse the responses applies for both groups except for the average value. It was calculated as "YES" for teachers to be 72 , and for students to be 60 (as shown in the italicised middle value in Table 1). Difference in the neutral value is due to the difference in number of items for each questionnaire: i.e. $(3 \times 24)$, and $(3 \times 20)$ respectively.

Table 1

Values assigned to the two questionnaires

\begin{tabular}{lll}
\hline & \multicolumn{1}{c}{ Teachers (46) } & \multicolumn{1}{c}{ Students (75) } \\
\cline { 2 - 3 } & \multicolumn{1}{c}{ Choice } & \multicolumn{1}{c}{ Choice } \\
\hline & SA = strongly agree (5) & SA = strongly agree (5) \\
& $\mathbf{A}=$ agree (4) & $\mathbf{A}=$ agree (4) \\
Likert 5-point scale & $\mathbf{N}=$ neutral (3) & $\mathbf{N}=$ neutral (3) \\
& $\mathbf{D}=$ disagree (2) & $\mathbf{D}=$ disagree (2) \\
& SD = strongly disagree (1) & $\mathbf{S D}=$ strongly disagree (1) \\
\hline \multirow{3}{*}{ Highest value } & & \\
Middle (neutral value) & 120 & 100 \\
Lowest value & $\mathbf{7 2}$ & 60 \\
\hline
\end{tabular}

The following example is taken from the teachers' questionnaire. The sixth item states, "Teachers should accept students' answers even if wrong in grammar or wrong in the choice of vocabulary items." The highest value should be 120 , the middle is 72 , and the lowest is 24 . Therefore, the statement weight is calculated in the following steps (calculations are presented in Table 2):

1. Tallying the number of responses under each choice.

2. Multiplying the number of responses under each choice by the assigned value (as coded above).

3. Summing up the total points for each statement.

4. Calculating the average (total points for each statement divided by the number of responses for that particular statement). 
5. Converting the average into a percentage as the real weight of the statement.

Table 2

The average number of a questionnaire and how this average (mean) is converted to percentages

\begin{tabular}{llllllc}
\hline \multicolumn{1}{c}{ STATEMENT } & SA & A & N & D & SD & TOTAL \\
\hline $\begin{array}{l}\text { Teachers should accept students' answers } \\
\text { even if wrong in grammar or wrong in the } \\
\text { choice of vocabulary items. }\end{array}$ & 11 & 23 & 0 & 12 & 0 & 46 \\
$\begin{array}{l}\text { Weight given for each choice } \\
\text { Total points for each choice }\end{array}$ & 5 & 4 & 3 & 2 & 1 & \\
\hline
\end{tabular}

Average for this statement is calculated as: $171 / 46=3.72(3.72 / 5=74 \%)$

In short, the Percentage Formula for this statement is: (average / $5 * 100$ ). The number 5 is the highest value an item statement can get. If an item gets above the neutral value (72\% for teachers, and $60 \%$ for the students), it indicates "YES" to the item (positive agreement), but if it gets less than neutral value, it means "NO", (negative agreement). For the full results of all items, see Appendices A and B. The above example shows "satisfaction", yet it is not a strong one because the result is slightly above the average point.

\section{Results and Discussion}

The teachers in this research consider certain aspects related to actual teaching highly, like 'teachers' knowledge of their students' attitudes towards learning English" (99\%), "calling their students by name when asking questions" (97\%) and "praising students' individual works and achievements" (98\%). Likewise, they strongly consider certain other aspects as very important keys for learning, such as "giving attention to the students' individual differences" (90\%), "creating a pleasant and supportive classroom environment" (93\%) and "establishing a good rapport with their students" (90\%). Using the white board in an organised manner (94\%) and using their teaching aids (94\%) are among the points mostly agreed upon. They also think highly of making use of available technology or teaching aids (97\%), changing their teaching techniques from time to time (96\%) and setting the goal for learning English for a good future (92\%). At another level, the teachers highly believe that increasing their students' self-confidence and autonomy (90\%), increasing their students' satisfaction and reward of learning English (93\%) and creating awareness among students that they can overcome difficulties as there is nothing impossible for the human mind (95\%) are very effective in making their students develop the love for learning the English language.

EFL teachers also believe that making their classes interactive (95\%), using lesson planning appropriate for each class (94\%) and using appropriate methods of teaching and suitable teaching aids (97\%) as excellent procedures to motivate their 
learners learn English. Furthermore, they admit that using appropriate verbal as well as non-verbal language (93\%) should make their students feel at ease with the use of the language (94\%). The use of positive words when dealing with students should lead to building bridges with them (96\%) and that teachers can be good "models" for their students so that they can follow them (97\%).

The reaction of the students to the items in the questionnaire is presented briefly here. The students praise highly (89\%) that their teachers call them by name when dealing with them in the classroom, and also, they react in quite a similar manner to the statement that their teachers praise their individual works (87\%). They responded positively to the fact that their teachers accept their talk in class even if there are mistakes in grammar and in the choice of vocabulary items (88\%) where teachers create a supportive atmosphere in the classroom.

The two statements of establishing good rapports with the students and using the white board in an organised manner have been equally valued extremely largely by the students (87\%) each. At another level, the points of telling students that English has a promising future and relating what is taught to learners' lives by teachers are well received by the students $(87 \%)$ and $(86 \%)$ respectively. With regard to making of class interactive, the use of appropriate teaching methods and the good care given to the different stages of the lesson are eminently considered by the students, (86\%), (85\%) and (83\%) respectively, as motivating techniques.

The students of this study deeply value the use of positive (good) word (87\%), the feeling at ease when using English (84\%) and the use of appropriate verbal and non-verbal language all by their teachers during classroom teaching and (81\%). The two statements of telling students of the promising futurity of English and those teachers being good models for their students are remarkably accepted by those students $(85 \%)$ each. The students also agree to the idea that their teachers are well aware of the fact that English is important for those students' higher education (87\%).

\section{Implications}

The teachers of this research strongly believe that having knowledge of their students' attitudes towards learning English, praising students' individual achievements, and calling them by name when asking questions are highly important in establishing a successful rapport between teachers and their students. All these are bound to ultimately lead to creating motivation towards learning English. These are excellent elements that make the teaching-learning process not only a physical mental process, but a cordially mutual relationship. The implication here is that those teachers highly consider giving attention to the students' individual differences, creating a pleasant and supportive classroom environment and establishing a good rapport with their students as strong bridges that can make both teachers and learners pass through to achieve successful learning outcomes. These implications are supported by Sugita and Takeuchi (2009).

From a pedagogical point of view, as supported by Brog (2003), the teachers in this study highly consider certain practical procedures used in classroom such as 
using the white board in an organised manner and using other teaching aids that are essential to ensure success in learning.

The teachers also pay a great attention to the psychological aspects that surround the learning of English. This is clear from the great care and concern they give to the development of their students' self-confidence and autonomy, increasing their students' satisfaction and reward of leaning English and creating awareness among students that they can overcome difficulties so as to energise their mental abilities to learn. The teachers are also well aware of the importance of making their classes interactive, using lesson planning appropriately for each class and using appropriate methods of teaching, carefully selecting suitable teaching aids confirm that these are among the things that maximise learning.

Furthermore, the teachers see the use of appropriate verbal as well as nonverbal language, making their students feel at ease with the use of the language, using positive words when dealing with students and being good models for their students to follow as exceptionally effective factors resulting in effective learning. This supports the idea that teachers strengthen the role of students' autonomy through guided motivation (Yang, 1998).

\section{Conclusion}

This study reinforces the findings of many studies in the field, particularly the strong correlational relationship between "[i]deal L2 self and motivated learning" (Prasangani, 2014, p. 33). Motivated teachers can help learners to exert more efforts of learning a foreign language in general. From the point of view of students, the most common techniques that teachers use to motivate them in the classrooms have a variety of facets, namely, encouragement, appraisal, tolerance, professionalism, friendly and positive attitude towards learners. On the other hand, the most common techniques that teachers should use to motivate their students in the classrooms are being aware of the needs of the students and the continuous evaluation of the learning situation, where teachers are supposed to act accordingly. Monitoring students learning and keeping motivation in mind are a good strategy to keep motivation present in the classroom activities and interactions. Teachers and students alike stress the importance of motivation in pushing learning ahead, and they almost share the same assumptions, but from different stances and perspectives.

\section{References}

Al-Kaboody, M. (2013). Second language motivation: the role of teachers in learners' motivation. Journal of Academic and Applied Studies, 3(4), 45-54.

Alrabai, F. (2014). Motivational practices in English as a foreign language classes in Saudi Arabia: Teachers' beliefs and learners' perceptions. Arab World English Journal, 5(1), 224-246.

Assalahi, H. (2013). Why is the grammar-translation method still alive in the Arab world? Teachers' beliefs and its implications for EFL teacher education. Theory and Practice in Language Studies, 3(4), 589-599. 
Bahous, R., Bacha, N. N., \& Nabhani, M. (2011). Motivating students in the EFL classroom: A case study of perspectives. English Language Teaching, 4(3), 33-43.

Borg, S (1998). Data-based teacher development. ELT Journal, 52(4), 273-281.

Brace, I. (2004). Questionnaire design: How to plan, structure and write survey material for effective market research. London: Kogan Page Publishers.

Brog, S. (2003). Teacher cognition in language teaching: A review of research on what language teachers think, know, believe and do. Language Teaching, 39(6), 81-109.

Brown, D. (1994). Principles of language learning and teaching (3rd ed.). Englewood Cliffs, NJ: Prentice Hall Regents.

Chambers, G. (1999). Motivating language learners. Bristol, England: Multilingual Matters.

Cheng, H. F., \& Dörnyei, Z. (2007). The use of motivational strategies in language instruction: The case of EFL teaching in Taiwan. International Journal of Innovation in Language Learning and Teaching, 1(1), 153-174.

Clément, R., Dörnyei, Z., \& Noels, K. A. (1994). Motivation, self-confidence, and group cohesion in the foreign language classroom. Language Learning, 44(3), 417-448.

Cohen, L., Manion, L., \& Morrison, K. (2007). Research methods in education ( $6^{\text {th }}$ ed.). London \& New York: Routledge.

Cook, V. (2013). Second language learning and language teaching. London \& New York: Routledge.

Cranmer, D. (1996). Motivating high level learners: Activities for upper intermediate and advanced learners. London: Longman.

Davis, A. (2003). Teachers' and students' beliefs regarding aspects of language learning. Evaluation and Research in Education, 17(4), 207-216.

Dörnyei, Z. (1994). Motivation and motivating in the foreign language classroom. The Modern Language Journal, 78(3), 273-284.

Dörnyei, Z. (1998). Motivation in second and foreign language learning. Language Teaching. 31(3), 117-135.

Dörnyei, Z. (2001) Teaching and researching motivation. Harlow: Longman.

Dörnyei, Z. (2003). Attitudes, orientations and motivations in language learning: Advances in theory, research and applications. Language Learning, 53(1), 332.

Dörnyei, Z. (2005). The psychology of the language learner. Mahwah, NJ: Lawrence Erlbaum.

Dörnyei, Z. (2008). Motivation strategies in the language classroom. Stuttgart, Germany: Ernst Klett Sprachen.

Dörnyei, Z. (2009). The L2 motivational self-system. Motivation, language identity and the $L 2$ self, 36(3), 9-42.

Dörnyei, Z. (2011). Motivating students in the language classroom. Cambridge: Cambridge University Press.

Dörnyei, Z., \& Ryan, S. (2015). The psychology of the language learner revisited. London \& New York: Routledge. 
Dörnyei, Z., \& Ushioda, E. (2011). Teaching and researching motivation (2nd ed.). London \& New York: Routledge.

Ekiz, S., \& Kulmetov, Z. (2016). The factors affecting learners' motivation in English language education. Journal of Foreign Language Education and Technology, 1(1), 18-38.

Fraenkel, J. R., Wallen, N. E., \& Hyun, H. H. (2011). How to design and evaluate research in education ( $8^{\text {th }}$ ed.). New York, NY: McGraw-Hill

Gonzales, R. D. (2010). Motivational orientation in foreign language learning: The case of Filipino foreign language learners. Gonzales, R. DLC. (2010). Motivational Orientation in Foreign Language Learning: The Case of Filipino Foreign Language Learners. TESOL Journal, 3, 3-28.

Hedge, T. (2001). Teaching and learning in the language classroom (Italic) (Vol. 106). Oxford, UK: Oxford University Press.

Ho, J. Y. (2016). English remedial instruction to enhance low-achieving students' vocabulary. Issues in Language Studies, 5(1), 64-83.

Jamieson, S. (2004). Likert scales: How to (ab)use them. Medical Education 38(12), 1217-1218.

Johnson, K. E. (1999). Understanding language teaching: Reasoning in action. Boston, MA: Heinle \& Heinle.

Koran, S. (2015). Motivational strategies in EFL classrooms and their feasibility in Iraqi context, International Journal of Linguistics and English Literature, 4(3), 36-45.

Kothari, C. R. (2004). Research methodology: Methods and technique ( $2^{\text {nd }}$ ed). New Delhi, India: New Age International.

Lamb, M. (2016). Motivation. In G Hall (Ed.), The Routledge handbook of English language teaching (pp 324-338). London \& New York: Routledge.

Lightbown, P. M., \& Spada, N. (2006). How languages are learned. Oxford: Oxford University Press.

Likert, R. (1932. A technique for the measurement of attitudes. Archives of Psychology 140, 1-55.

Moore, A. (2004). Becoming an effective teacher: Dominant discourses in teaching and teacher education. London \& New York: Routledge.

Moskovsky, C., Alrabai, F., Paolini, S., \& Ratcheva, S. (2013). The effects of teachers' motivational strategies on learners' motivation: A controlled investigation of second language acquisition. Language learning, 63(1), 34-62.

Nadeem, M. (2013). Effect of the role of teacher in EFL teaching through interactive approach at public sector schools. The International Journal of Engineering and Science, 2(1), 209-215.

Prasangani, K. S. N. (2014). Malaysian L2 learners' English learning motivation: A study of goals, attitudes and self. Issues in Language Studies, 3(1), 24-35.

Ramage, K. (1990). Motivational factors and persistence in foreign language study. Language Learning, 40(2), 189-219.

Reeve, J., \& Jang, H. (2006). What teachers say and do to support students' autonomy during a learning activity. Journal of Educational Psychology, 98(1), 209-218. 
Rehman, A., Bilal, H., Sheikh, A., Bibi, N., \& Nawaz, A. (2014). The role of motivation in learning English language for Pakistani learners. International Journal of Humanities and Social Science, 4(1), 254-258.

Ruesch, A., Bown, J., \& Dewey, D. P. (2012). Student and teacher perceptions of motivational strategies in the foreign language classroom. Innovation in Language Learning and Teaching, 6(1), 15-27.

Spolsky, B. (1990). Conditions for second language learning. Oxford: Oxford University Press.

Sugita, M., \& Takeuchi, O. (2009). What can teachers do to motivate their students? A classroom research on motivational strategy use in the Japanese EFL context. Innovation in language Learning and Teaching, 4(1), 21-35.

Tuan, L. T. (2012). An empirical research into EFL learners' motivation. Theory and Practice in Language Studies, 2(3), 430-439.

Williams, M., \& Burden, R. (2002). Psychology for language teachers. Cambridge: Cambridge: University Press.

Yang, N. D. (1998). Exploring a new role for teachers: Promoting learner autonomy. System, 26(1), 127-135. 


\section{Appendix A: Analysis of teachers' questionnaire}

\section{Dear teacher,}

This questionnaire intends to get your opinion on how you exert efforts and use classroom to motivate your students learn English. You are kindly requested to put a tick (ü) against the choice that you see suitable, and according to your opinion. We assure you that the data you provide will be used strictly and only for the purposes for research purposes, hoping that you provide your answers honestly. This questionnaire is optional and you can withdraw at any time if you are not interested in competition.

CODE: $\mathbf{S A}=$ strongly agree, $\mathbf{A}=$ agree, $\mathbf{N}=$ neutral, $\mathbf{D}=$ disagree, and $\mathbf{S D}=$ strongly disagree.

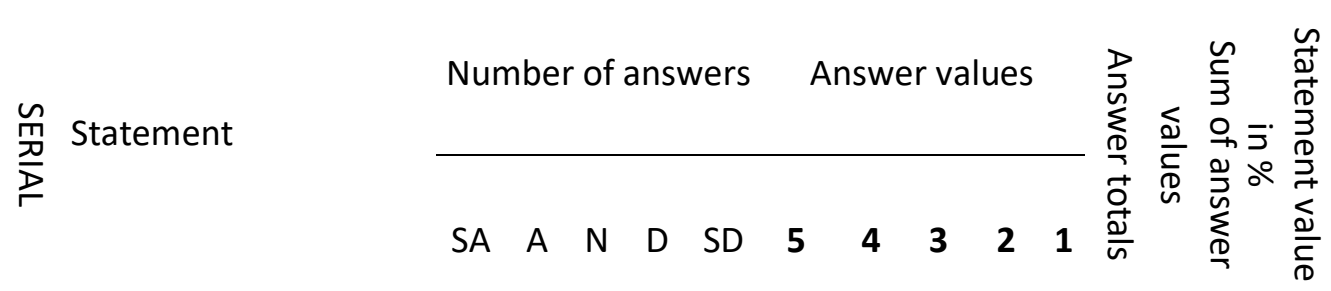

Teachers should try to know about their

1 students' attitudes $\begin{array}{lllllllllllll}43 & 3 & 0 & 0 & 0 & 215 & 12 & 0 & 0 & 0 & 46 & 227 & 99 \%\end{array}$ towards learning English.

Teachers should call

2 students by name when asking questions $\begin{array}{lllllllllllll}38 & 8 & 0 & 0 & 0 & 190 & 32 & 0 & 0 & 0 & 46 & 222 & 97 \%\end{array}$ and assigning tasks. Teachers should praise

3 students' individual works and $\begin{array}{lllllllllllll}41 & 5 & 0 & 0 & 0 & 205 & 20 & 0 & 0 & 0 & 46 & 225 & 98 \%\end{array}$ achievement. Teachers should look into their students'

4 past experience; how they were taught $\begin{array}{lllllllllllll}21 & 25 & 0 & 0 & 0 & 105 & 100 & 0 & 0 & 0 & 46 & 205 & 89 \%\end{array}$ before getting into the university. Teachers should give

$\begin{array}{lllllllllllllll}5 & \text { attention to students' } & 22 & 24 & 0 & 0 & 0 & 110 & 96 & 0 & 0 & 0 & 46 & 206 & 90 \%\end{array}$ individual differences.
} 
Teachers should accept students' answers even if wrong in grammar or wrong in the choice of vocabulary items. Teachers should create

7 a pleasant and supportive classroom environment. Teachers should

8 establish a good rapport with the students.

Teachers should use

9 the white board in an organized manner. Teachers should make 10 use of any available technology/ teaching aids.

Teachers should

11 change their teaching techniques from time to time.

Teachers should increase the learner's

12 goal of learning the language in such a way that it has a good/ promising future. Teachers should relate

13 what they teach to the learner's life. Teachers should try to 14 increase the students' self-confidence and their autonomy. Teachers should try to increase the students'

15 satisfaction and reward of leaning English. $\begin{array}{lllllllllllll}11 & 23 & 0 & 12 & 0 & 55 & 92 & 0 & 24 & 0 & 46 & 171 & 74 \%\end{array}$ $\begin{array}{lllllllllllll}31 & 15 & 0 & 0 & 0 & 155 & 60 & 0 & 0 & 0 & 46 & 215 & 93 \%\end{array}$

$\begin{array}{lllllllllllll}23 & 23 & 0 & 0 & 0 & 115 & 92 & 0 & 0 & 0 & 46 & 207 & 90 \%\end{array}$

$\begin{array}{lllllllllllll}32 & 14 & 0 & 0 & 0 & 160 & 56 & 0 & 0 & 0 & 46 & 216 & 94 \%\end{array}$

$\begin{array}{lllllllllllll}39 & 7 & 0 & 0 & 0 & 195 & 28 & 0 & 0 & 0 & 46 & 223 & 97 \%\end{array}$

$\begin{array}{lllllllllllll}37 & 9 & 0 & 0 & 0 & 185 & 36 & 0 & 0 & 0 & 46 & 221 & 96 \%\end{array}$

$\begin{array}{lllllllllllll}27 & 19 & 0 & 0 & 0 & 135 & 76 & 0 & 0 & 0 & 46 & 211 & 92 \%\end{array}$

$\begin{array}{lllllllllllll}19 & 27 & 0 & 0 & 0 & 95 & 108 & 0 & 0 & 0 & 46 & 203 & 88 \%\end{array}$ $\begin{array}{lllllllllllll}22 & 24 & 0 & 0 & 0 & 110 & 96 & 0 & 0 & 0 & 46 & 206 & 90 \%\end{array}$ $\begin{array}{lllllllllllll}31 & 15 & 0 & 0 & 0 & 155 & 60 & 0 & 0 & 0 & 46 & 215 & 93 \%\end{array}$ 
Teachers should create awareness among students that they can

16 overcome difficulties as there is nothing impossible for the human mind.

Teachers should try to

17 make their class interactive.

$\begin{array}{lllllllllllll}34 & 12 & 0 & 0 & 0 & 170 & 48 & 0 & 0 & 0 & 46 & 218 & 95 \%\end{array}$ Teachers should use

18 lesson planning appropriate for each $\begin{array}{lllllllllllll}35 & 11 & 0 & 0 & 0 & 175 & 44 & 0 & 0 & 0 & 46 & 219 & 95 \%\end{array}$ class.

Teachers should use

19 appropriate methods of teaching \& suitable teaching aids.

Teachers should use

20 appropriate verbal as well as non-verbal $\begin{array}{lllllllllllll}33 & 13 & 0 & 0 & 0 & 165 & 52 & 0 & 0 & 0 & 46 & 217 & 94 \%\end{array}$ language.

Teachers should make students feel at ease with the use of the $\begin{array}{lllllllllllll}32 & 14 & 0 & 0 & 0 & 160 & 56 & 0 & 0 & 0 & 46 & 216 & 94 \%\end{array}$ language.

Teachers should use positive words when 22 dealing with students so as to build bridges $\begin{array}{lllllllllllll}38 & 8 & 0 & 0 & 0 & 190 & 32 & 0 & 0 & 0 & 46 & 222 & 97 \%\end{array}$ $\begin{array}{lllllllllllll}30 & 16 & 0 & 0 & 0 & 150 & 64 & 0 & 0 & 0 & 46 & 214 & 93 \%\end{array}$ with such students.

Teachers should be good models for their

23 students so that they can follow such good $\begin{array}{lllllllllllll}38 & 8 & 0 & 0 & 0 & 190 & 32 & 0 & 0 & 0 & 46 & 222 & 97 \%\end{array}$ models.

Teachers should create awareness among

24 their students that English is important for $\begin{array}{lllllllllllll}27 & 19 & 0 & 0 & 0 & 135 & 76 & 0 & 0 & 0 & 46 & 211 & 92 \%\end{array}$ their higher/ further education 


\section{Appendix B: Analysis of students' questionnaire}

\section{Dear Student,}

This questionnaire is intended to get your opinion on how the teacher(s) of English motivate you in class in order to learn English effectively. You are requested to put a tick (ü) against the choice that you see suitable, and according to your observation of your teacher and experience in the classroom. Your responses will be kept confidential and will be used for research purposes to encourage your teachers to teach better. Kindly answer with honesty. This questionnaire is optional and you can withdraw at any time if you are not interested in competition.

CODE: $\mathbf{S A}=$ strongly agree, $\mathbf{A}=$ agree, $\mathbf{N}=$ neutral, $\mathbf{D}=$ disagree, and $\mathbf{S D}=$ strongly disagree.

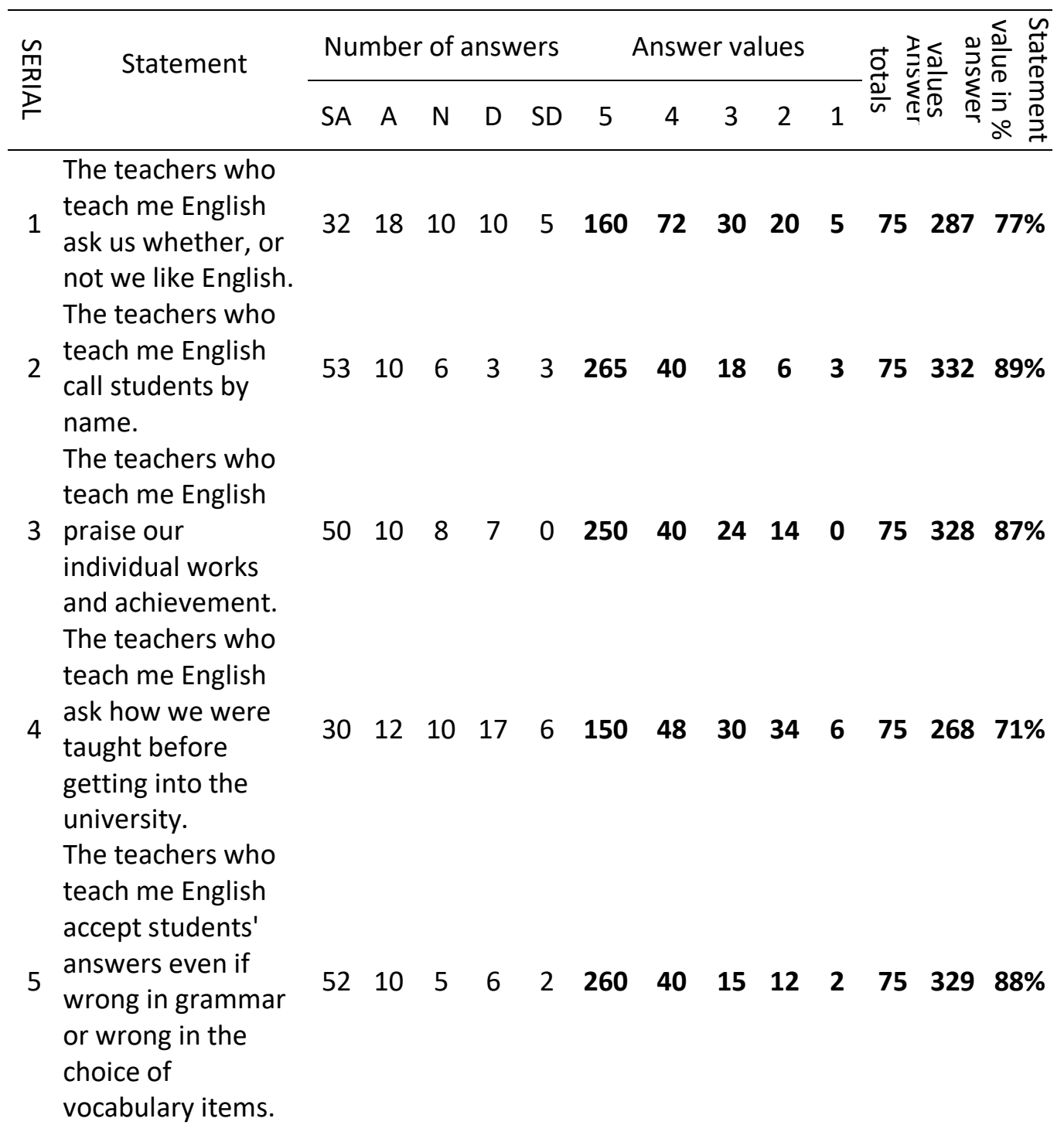


The teachers who teach me English create a pleasant and supportive $\begin{array}{lllllllllllll}42 & 12 & 10 & 6 & 5 & 210 & 48 & 30 & 12 & 5 & 75 & 305 & 81 \%\end{array}$ classroom environment. The teachers who teach me English

7 establish a good rapport with the students.

The teachers who teach me English

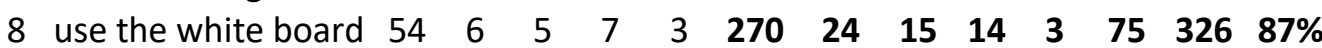
in an organized manner. The teachers who teach me English change their

9 teaching techniques from time to time; giving different tasks, telling little stories etc..

The teachers who teach me English tells the students that English has a $\begin{array}{lllllllllllll}50 & 10 & 8 & 7 & 0 & 250 & 40 & 24 & 14 & 0 & 75 & 328 & 87 \%\end{array}$ good/ promising future.

The teachers who teach me English

11 relate what they teach to the learner's life. The teachers who

12 teach me English make their class $\begin{array}{lllllllllllll}31 & 9 & 11 & 15 & 9 & 155 & 36 & 33 & 30 & 9 & 75 & 263 & 70 \%\end{array}$ interactive.

The teachers who teach me English

13 take good care of the beginning, middle and end of the lesson. 
The teachers who teach me English

14 use appropriate teaching methods \& $\begin{array}{lllllllllllll}48 & 9 & 8 & 10 & 0 & 240 & 36 & 24 & 20 & 0 & 75 & 320 & 85 \%\end{array}$ suitable teaching aids.

The teachers who teach me English use appropriate

15 verbal as well as $\begin{array}{lllllllllllll}33 & 21 & 11 & 10 & 0 & 165 & 84 & 33 & 20 & 0 & 75 & 302 & 81 \%\end{array}$ non-verbal language while teaching.

The teachers who teach me English

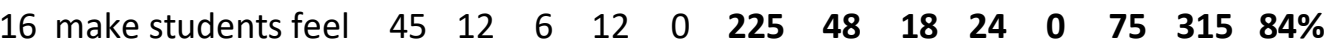
at ease with the use of the language. The teachers who teach me English

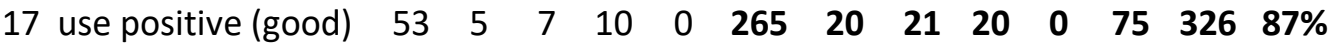
words when dealing with students.

The teachers who teach me English

18 tell their students to learn English for a promising future. The teachers who teach me English

19 are good models for $48 \quad 7 \quad \begin{array}{llllllllllll}12 & 8 & 0 & 240 & 28 & 36 & 16 & 0 & 75 & 320 & 85 \%\end{array}$ their students to follow.

20

The teachers who teach me English make their students aware of the fact that English is $\begin{array}{lllllllllllll}51 & 5 & 15 & 4 & 0 & 255 & 20 & 45 & 8 & 0 & 75 & 328 & 87 \%\end{array}$ important for their higher/ further education.

$\begin{array}{lllllllllllll}47 & 8 & 10 & 10 & 0 & 235 & 32 & 30 & 20 & 0 & 75 & 317 & 85 \%\end{array}$ 